\author{
K. Tojibaev, N. Beshko, O. Turginov \& D. Mirzalieva
}

\title{
New records for Fabaceae in the flora of Uzbekistan
}

\begin{abstract}
Tojibaev, K., Beshko, N., Turginov, O. \& Mirzalieva, D.: New records for Fabaceae in the flora of Uzbekistan. - Fl. Medit. 24: 25-35. 2014. — ISSN: 1120-4052 printed, 2240-4538 online.

The Republic of Uzbekistan is a Central Asian country with rich native flora. The territory belongs to the Irano-Turanian region in the Ancient Mediterranean (Tethyan) floristic subkingdom of Holarctic. The flora of Uzbekistan accounts more than 4250 species of vascular plants including large numbers of endemic species, but the check-list is still incomplete. 17 new records for Fabaceae family in the flora of Uzbekistan were found in 2012-2013 during the field studies and examination of herbarium collections of TASH.
\end{abstract}

Key words: biogeography, new localities, Central Asia, vascular plants.

\section{Introduction}

The Republic of Uzbekistan is a Central Asian country with rich native flora. The total land area is about $447,000 \mathrm{~km}^{2}$. Uzbekistan occupies a position of great bio-geographical importance. This territory belongs to the Turanian (or Aralo-Caspian) and Turkestan (or Central Asian mountain) Provinces of the Irano-Turanian region in the Tethyan (Ancient Mediterranean) floristic subkingdom of Holarctic (Takhtajan 1986). The region is one of the world's major centers of plant diversity. Almost $85 \%$ of the country is occupied by deserts; about $15 \%$ covered by mountains and foothills. The flora of Uzbekistan accounts more than 4250 species of vascular plants including large numbers of endemic, endangered and globally important species. During the last 20 years three new genera and about 100 new species were described. But the floristic data is imperfect yet for several regions of Uzbekistan including the western part of the Zeravschan and Gissar ridges, Babatag ridge, Fergana valley, etc. Even nowadays, studies are continuing and new discoveries appear regularly.

Since 2012 the research team of the Central Herbarium of Uzbekistan (TASH) is compiling the digital database of plant diversity of country with application of GIS software. This work is based on current field surveys and analysis of herbarium materials. The most important source of floristic information is TASH, the largest collection of Central Asian plants in the world. There are over 1.5 million herbarium specimens collected since 1840 from all regions of the Central Asia. During 2012-2013, information from more than 
65,000 herbarium specimens was included into the database and more than 100 new records in the flora of Uzbekistan were found. These results have a great importance for compiling the new checklist of the flora of Uzbekistan.

This paper provides information about 17 new records for Fabaceae family in the flora of Uzbekistan. They were found in 2012-2013 during the field studies and examination of herbarium collections of TASH.

\section{Materials and methods}

Our field researches were conducted in 2012-2013 on mountainous regions of Uzbekistan by traditional methods. The coordinates of plants species location were recorded using GPS device. In TASH, we studied all herbarium specimens of Astragalus L., Oxytropis DC. and other large genera of Fabaceae collected from Uzbekistan (more than 10,000 specimens total). We also investigated the Herbarium of the Komarov Botanical Institute, St. Petersburg (LE). The data of vouchers were entered into the Microsoft Excel table, geo-referenced and imported into ArcGIS 9.3, transformed to a point map layer. We used the Google Earth software for geo-referencing of collection sites of historical herbarium specimens. A WGS84 Geographic coordinate system was used as a reference datum. The identification of herbarium specimens belonging to new records was revised by authors. Accepted names of the species are given according to www.ipni.org and www.theplantlist.org.

\section{Results}

\section{Astragalus L.}

Astragalus L., the largest genus in Angiosperms with about 2500-3000 species in the world, also is the largest genus in the flora of Uzbekistan and Central Asia. In TASH, there are more than 12,000 herbarium specimens of Astragalus, collected from all regions of the Central Asia. About 7,000 of them were collected from Uzbekistan. Main depositories of Central Asian specimens are the Komarov Botanical Institute, St. Petersburg (LE) and the Moscow State University (MW) as well. This material was three times included in revisions of Astragalus of Uzbekistan during the XX century. First, the revision of Astragalus for the former USSR was compiled by A.G. Borissova \& al. (1946). Next, the treatment of this genus (254 species) prepared by N.F. Gontscharow (1955) was published in the "Flora of Uzbekistan" (1955). In conclusion, the synopsis of Astragalus for the ten-volume edition "Conspectus Florae Asiae Mediae" was elaborated by M.N. Abdullaeva \& al. (1981). According to this source, 587 species were recorded for Central Asia and 257 species were recorded for Uzbekistan, many of them are endemic.

Our studies reveal that 268 species of Astragalus are found in the present political boundaries of Uzbekistan. Out of them, 6 species were described after publication of 6 th volume of "Conspectus ..." (Abdullaeva \& al. 1981). 6 new records were discovered for Uzbekistan (Astragalus artemisiformis Rassul., A. bosbutooensis Nikitina \& Sudn., A. heterotrichus Gontsch., A. sericeopuberulus Boriss. A. taldycensis Franch., A. varzobicus 
Gontsch.) (Fig. 1). These records were overlooked by previous researchers owing to great amount of material and lack of IT technology.

Three new records in the flora of Uzbekistan belong to section Myobroma (Stev.) Bunge. This large section accounts about 275 species widespread from Europe and Northern Africa to Siberia, China and India. 71 species of them are recorded in Central Asia (Abdullaeva \& al. 1981).

\section{Astragalus sericeopuberulus Boriss.}

Astragalus sericeopuberulus Boriss. belongs to group of species with glabrous corolla and with leaflets densely hairy on both sides. According to the "Conspectus ..." (Abdullaeva \& al. 1981), this species is widespread in Tajikistan on Gissar and Zeravschan ridges.

During examination of TASH collection we found one specimen of A. sericeopuberulus from the Uzbekistan part of the Gissar ridge:

Uzbekistan: Western Pamir-Alay, Kashka-Darya river basin, Tankhaz-Darya river valley, near Shurasay village, near river head of left horn of Kaynar-say river, 17 VII 1955, Pjataeva, 2066 (TASH).

\section{Astragalus taldycensis Franch.}

Abdullaeva \& al. (1981) reported this species for Kazakhstan and Kyrgyzstan including Kungey, Kyrgyz, Talas Alatau, Chatkal, Alay, Transalay and Peter the Great ridges, the Alay valley. In TASH, there are detected several herbarium specimens collected from Shachimardan river basin from territory of Uzbekistan:

Uzbekistan: Alay ridge, near Shachimardan village, 15 VII 1936, Chrzanowsky \& Tamilova, sn; Alay ridge, near Shachimardan village, 05 VI 1947, Shafeev, sn; Western part of Alay ridge, near Shachimardan village, 20 VI 1963, Shonazarov, sn (TASH), etc.

Some specimens were collected from Kyrgyz part of Alay ridge:

Kyrgyzstan: Alay ridge, Shachimardan river basin, Duoba alpinist camp, upper belt of mountains, 15 VI 1967, Khalkuziev, sn; Alay ridge, northern slope, Soh river basin, river head of Raut-say, near Simap mine, juniper forest, 08 VII 1962, Zuckervanik, 612 (TASH), etc.

Though, A. taldycensis was not included in the checklist of the flora of Shachimardan river basin (Khalkuziev 1971).

\section{Astragalus varzobicus Gontsch.}

The species was described from Varzob river basin in Tajikistan (Borissova \& al. 1946). Its distribution area was described differently in various publications and the question of its presence in territory of Uzbekistan was not decided perfectly clear. According to Borissova \& al. (1946), the species occurrs in Tajikistan and Uzbekistan on southern slopes of Gissar ridge from Varzob river basin to Ketmen-Chapty mts., on Sarsarak ridge and in northern part of Babatag ridge. But Gontscharow (1955) wrote that A. varzobicus possibly could be found in Uzbekistan on the southern slopes of the Gissar ridge, in Tupalang river valley. According Abdullaeva \& al. (1981), the distribution area of this species located within Tajikistan (the Gissar ridge and the low mountains of Southern Tajikistan). 
During the examination of TASH collection we found several specimens collected from Uzbekistan since 1929-1930:

Uzbekistan: Chulbair mts., the top point of Khodzha-barku, stony slope, 29 VI 1929, A. Vvedensky, 409; Baysun mts., Tuada, slopes of Ketmen-chapty ridge, juniper forests, 22 V 1930, Lepyoshkin, sn; Gissar ridge, Sangardak river basin, Sangardak river valley, near confluence with Bakhchi-say river, 02 VI 1948, A. Pjataeva, 94; Gissar ridge, Tupalang river basin, slope to Guliob, 1520 m a.s.l., 05 V 1987, I.I. Maltzev, sn (TASH), etc.

During our studies we also collected this species from south-western branches of the Gissar ridge:

Uzbekistan: Chulbair mts., 3842’76” N, 67²8’62” E, stony-rubbly slope, $2736 \mathrm{~m}$ a.s.1., 18 VI 2013, O. Turginov, sn (TASH).

These materials provides documentary evidence of widespread occurrence of $A$. varzobicus in the Uzbekistan part of the Gissar ridge. Also there is one specimen collected on Tajikistan part of Babatag ridge near the border with Uzbekistan.

\section{Astragalus bosbutooensis Nikitina \& Sudn.}

According to Abdullaeva \& al. (1981) and Lazkov \& Sultanova (2011), the species belongs to Astragalus sect. Xiphidium Bunge and is a local endemic occurring on the southern side of Chatkal ridge and Bozbu-Too mountains. Two specimens of $A$. bosbutooensis collected from Uzbekistan were found in TASH:

Uzbekistan: Kurama ridge, between Pap town and Charkisar village, in Artemisia steppe, 12 V 1950, M.M. Arifhanova, 95-1; Chatkal ridge, Bashkizilsay river basin, VII 1972, T. Shakirova, sn (TASH).

Because of the rarity of this species in the Uzbekistan part of the Chatkal ridge, it remained overlooked by recent researchers (Krasovskaja \& Levichev 1986; Tojibaev 2010). The new records are new both to the flora of Uzbekistan and to the flora of the Chatkal Nature Reserve, significantly expanding the species distribution area.

\section{Astragalus heterotrichus Gontsch.}

Astragalus section Macrocystis Popov is represented in Central Asia by 12 species. They are the local endemics of Western Tien-Shan and Pamir-Alay mountains. 10 of them were recorded for Uzbekistan (Gontscharow 1955; Abdullaeva \& al. 1981). According to Abdullaeva \& al. (1981) A. heterotrichus Gontsch., the 11th species of section, and it is widespread in Tajikistan, on Gissar, Karategin, Darvaz and Peter I ridges (Abdullaeva \& al. 1981). There are several specimens of species collected from Tajikistan and one specimen from the Uzbek part of the Gissar ridge:

Uzbekistan: Gissar ridge, southern side, near Zevar village, western slope, infrequent, solitary, 15 VI 1929 Kuznetsova, sn (TASH).

\section{Astragalus artemisiformis Rassul.}

The 12th species of the section Macrocystis was described from the watershed of Karatag and Khanaka rivers (Tajikistan) in 1979. The holotype is stored in Dushanbe:

Tajikistan: Declivie australe jugi Hissarici, inter fluvios Chanaka et Karatag ad fl. BovaMazari, 2400 m, 08 VII 1948, A.A. Nikitin \& A.G. Borissova, 170 (TAD).

It is an insufficiently explored species which was not included to the check-list of 




Fig. 1. New localities of species of Astragalus L. in Uzbekistan.

Central Asian species of the section (Abdullaeva \& al. 1981). In TASH, there is stored one specimen collected from Uzbekistan and determined by R.V. Kamelin:

Uzbekistan: Western Gissar, Tupalang river basin, in the vicinity of the Khurvatan village, on the soft slope, 13 VIII 1947, Sumnevicz \& Djangurazow, sn (TASH).

\section{Oxytropis DC.}

The genus Oxytropis DC. is one of largest genera in Fabaceae with 166 species in Central Asia (Filimonova 1983). Gontscharow (1955) reported 34 species of them in Uzbekistan. During the examination of TASH collection we found 3 new records of Oxytropis for Uzbekistan (Fig. 2). These species were collected nearby the borders with Tajikistan and Kyrgyzstan more than 30 years ago and further studies are needed to relocate them in the wild.

\section{Oxytropis babatagi Abdusal.}

O. babatagi Abdusal. is an endemic of the Babatag ridge. It was described from Tajikistan part of this transboundary ridge (Abdusalamova 1978). Two specimens collected from Uzbekistan theretofore the species description are stored in TASH:

Uzbekistan: Surkhandarya region, Babatag ridge, the top of ridge, in juniper zone and among pistachios, 07 V 1953, E.E. Korotkova, 3890; Babatag ridge, the top of Central Babatag, juniper forests, 2200 m a.s.l., 13 VII 1936, Lepyoshkin \& Mukhamedzanov, 534 (TASH). 


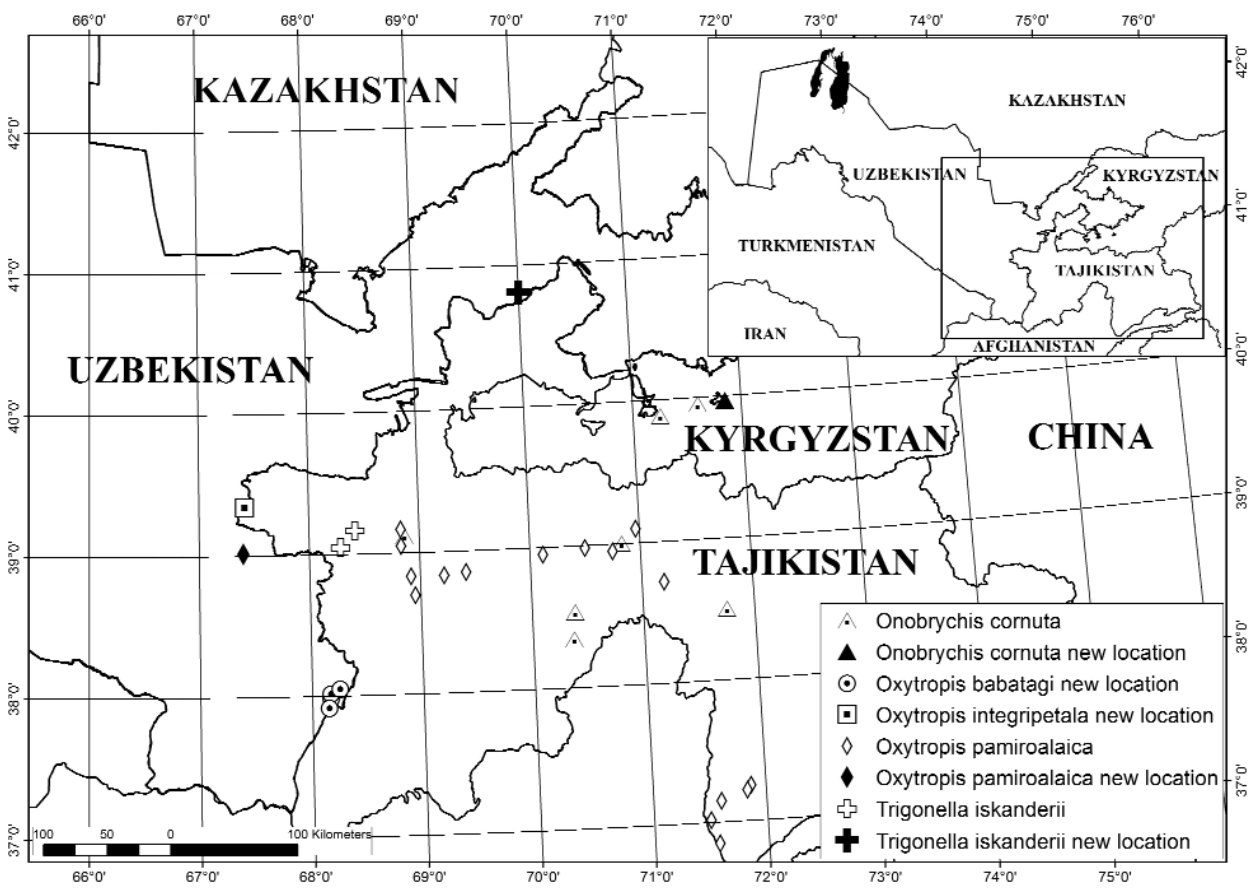

Fig. 2. New localities of species of Onobrychis Mill., Oxytropis DC. and Trigonella L. in Uzbekistan.

\section{Oxytropis integripetala Bunge}

$O$. integripetala is an insufficiently explored species, it is known by several specimens collected from Tajikistan and Kyrgyzstan. According to Filimonova (1983), its distribution area includes the Turkestan, Alay and Mogoltau ridges. We found a specimen collected from western part of the Zeravschan ridge:

Uzbekistan: Samarkand region, Urgut district, sovkhoz Urgut, $5 \mathrm{~km}$ to the $\mathrm{SW}$ from Kattakan village, left bank of Kattakan-say stream, western slope, community of Ferula, Perovskia and Artemisia, VIII 1979, collector is unknown, 49 (TASH).

\section{Oxytropis pamiroalaica Abdusal.}

This species is widespread in Tajikistan (Gissar, Peter I, Darvaz ridges and Western Pamir) (Abdusalamova 1978; Filimonova 1983). One specimen collected from Uzbekistan was found in TASH:

Uzbekistan: Shakhrisyabz district, near Kyzyl-emchak village, Yurtijala, 12 VII 1969, S.M. Mustafaev, 189 (TASH).

\section{Chesneya Lindl.}

The genus Chesneya Lindl. is represented by 21 species in Central Asia. A.I. Vvedensky (1955) in the "Flora of Uzbekistan", and also R.M. Vinogradova \& R.V. Kamelin (1981) 
reported only three species for this genus in Uzbekistan (C. ternata (Korsh.) Popov, $C$. tribuloides Nevski, C. turkestanica Franch.). Three new records for Chesneya were found in Uzbekistan (Fig. 2).

\section{Chesneya crassipes Boriss.}

Chesneya crassipes Boriss. is an endemic of Pamir-Alay and its distribution area includes the Gissar, Darvaz, Peter the Great ridges and Pamir, only for Tajikistan. (Vinogradova \& Kamelin 1981). We registered it from western part of Baysuntau mountains:

Uzbekistan: Baysuntau ridge, river head of Gumatak, Parakhnaur river basin, $38^{\circ} 35^{\prime} 48^{\prime \prime} \mathrm{N}, 67^{\circ} 33^{\prime} 77^{\prime}$ ' E, sparse juniper forest, stony-rubbly soil, $2046 \mathrm{~m}$ a.s.1, $04 \mathrm{~V}$ 2013, O. Turginov, sn; Pamir-Alay, Khodzha-Gurgur-ata mts., 38²9'28” N, 67²4'66" E, stony slopes, 2252 m a.s.1., 12 VI 2013, O. Turginov, sn; Baysun mts., Ketmen-chapty ridge, $2 \mathrm{~km}$ to the north, on stony slopes, $24 \mathrm{~V} \mathrm{1980,} \mathrm{Nabiev,}$ Shermatov, Kazakboev \& Levichev, 298 (TASH).

\section{Chesneya hissarica Boriss.}

Chesneya hissarica Boriss. is an endemic of Gissar-Darvaz region. Borissova \& al. (1955) and Vinogradova \& Kamelin (1981) do not report this species from Uzbekistan. During the inventory of TASH collections we found more than 30 specimens collected from Uzbekistan in 1919-1948:

Uzbekistan: Gissar ridge, Tupalang river basin, between the Zardolu-pas and Shatrut villages, 26 VI 1948, A. Pjataeva, 756; Gissar ridge, Sangardak river basin, upper reaches of the Ak-su river, 05 VI 1948, A. Pjataeva, 218; Chulbair mts., speckled low mountains near Lukka village, 19 VI 1929, Vvedensky, 359; Yakkabag distr., Tashkurgan, 28 V 1916, M.G. Popov, 1027 (TASH), etc.

These collections show that $C$. hissarica is widespread in the Uzbekistan part of the Gissar ridge. On the northern slopes of the Gissar ridge its westernmost localities are situated in the Kyzyl-su river basin near Tashkurgan village (Popov 1927).

\section{Chesneya trijuga Boriss.}

According Vinogradova \& Kamelin (1981), this species occurs in several localities in the Kyrgyz part of the Alay ridge (Shaid and Jeptik river basins). During the study of the flora of Shahimardan river basin, P.H. Khalkuziev (1971) collected several herbarium specimens of this plant:

Uzbekistan: Alay ridge, Shahimardan river basin, vicinity of Yardan village, $10 \mathrm{VI}$ 1968, P.H. Khalkuziev, sn; Alay ridge, Shahimardan river basin, Yordan, Kizil-Tag, limestone, 28 V 1967, P.H. Khalkuziev, sn; Alay ridge, Shahimardan river basin, Koksu river ravine, on stony slopes, 29 VII 1966, P.H. Khalkuziev, sn; Alay ridge, Shahimardan river basin, Buva river basin, on limestones, 07 IX 1968, P.H. Khalkuziev, sn (TASH).

\section{Hedysarum L.}

The genus Hedysarum L. accounts 72 species in the flora of Central Asia (Kovalevskaja 1981). Many of them are local endemics of Tien-Shan and Pamir-Alay 
mountains. In some cases, Hedysarum enters into the composition of polymorphous genera of local mountain floras, such as Astragalus L., Allium L., Cousinia Cass., Gagea Salisb. genera (Tojibaev 2010). We found three new records for this genus in Uzbekistan (Fig. 3).

\section{Hedysarum denticulatum Regel}

This species is widespread in Tajikistan (Zeravschan ridge, Gissar, Peter I, Vahsh, Darvaz, Hazratisho, Karategin ridges and low mountains of Southern Tajikistan) and Kyrgyzstan (Alay, Trans-Alay ridges). Korotkova (1955) and Kovalevskaja (1981) do not report this species from Uzbekistan. During our field work $H$. denticulatum was collected from the Uzbekistan part of the Gissar ridge:

Uzbekistan: Machay River Basin, Yukari Machay, Sharshara Hole, stony substratum, 06 VI 2012, Turginov, 490 (TASH).

In addition, in TASH we found another specimen collected from this region:

Uzbekistan: Chulbair mountains, alpine vegetation, 01 VII 1941, Popova, 868 (TASH).

These specimens extend the western limit of the distribution area of $H$. denticulatum up to the Uzbek part of the Gissar ridge. In the Tajik part of its area H. denticulatum is a widespread fodder plant, sometimes a weed in crops, but in Chulbair mountains it is quite rare.

\section{Hedysarum turkestanicum Regel et Schmalh.}

According to Kovalevskaja (1981), this species is an endemic of the southern slopes of the Chatkal ridge (South-Western Tian Shan, Kyrgyzstan). The majority of herbarium specimens kept at TASH were collected from that area. However, the data of herbarium vouchers do not allow us to affirm precisely whether those specimens were collected from Uzbekistan or not:

Nanay, 12 VI 1954, Galkina, sn; Kyrgyz SSR, east of Pishkaran, on the road to Padshaata, Botriochloa steppe, 19 VII 1951, Galkina, 329, 338; Kyrgyz SSR, east of Pishkaran, on the road to Karavan, 1951, Galkina \& Nabiev, sn (TASH).

Those specimens may have been collected in Uzbekistan or at least in its border areas. It is difficult to identify the exact coordinates from those vouchers, because there is 8 to 12 $\mathrm{km}$ from Pishkaran village (north of the Fergana Valley, Uzbekistan) to the border with Kyrgyzstan. At the time of collecting, the southern piedmonts of Chatkal ridge were not used for farming and were covered by ephemeral and ephemeroid vegetation, including plant associations with the dominance of beard grass (Botriochloa ishaemum) (Kudryashev 1938).

Interesting record of $H$. turkestanicum was made on the opposite, southern part of the Fergana Valley, from the Soh river basin in Alay ridge:

Uzbekistan: Fergana Valley, vicinity of Uch-Yer on the north-east side, 12 VI 1949, Sahobiddinov \& Li, 782, 818 (TASH).

These plants differ from the typical $H$. turkestanicum in more lowered calyces, with the reddish naked part of calyx teeth being less pronounced.

\section{Hedysarum minjanense Rech. f. [Hedysarum cephalotes Franch.]}

This species is widespread in Kazakhstan, Kyrgyzstan, Tadzhikistan, Afghanistan, Pakistan, in north-western regions of China and India. In Pamir-Alay it occurs from Pamir to south-west- 


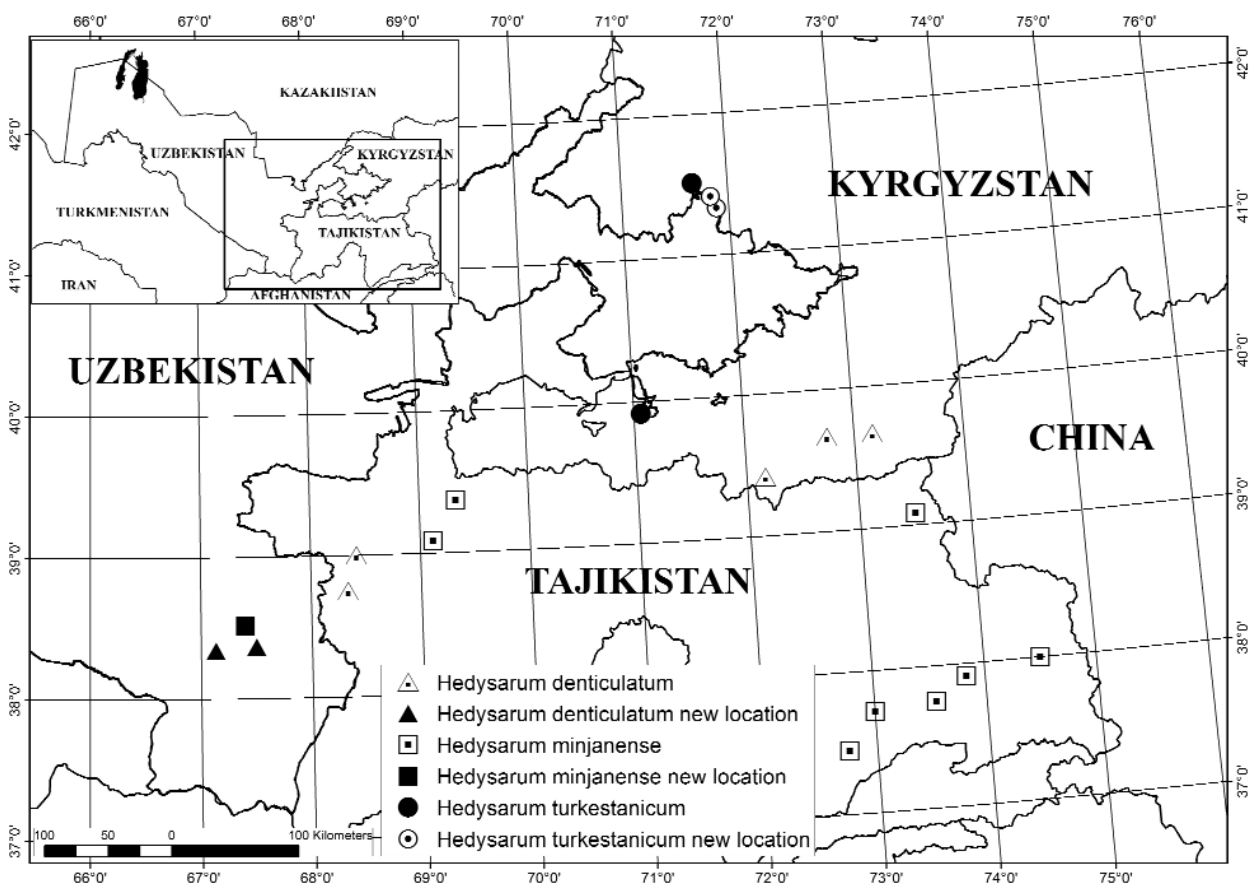

Fig. 3. New localities of species of Hedysarum L. in Uzbekistan.

ern branches of the Gissar ridge. Nevertheless Borissova \& al. (1955) and Kovalevskaja (1981) do not report this species from Uzbekistan. The specimens of $H$. minjanense, collected from the Uzbek part of the Gissar ridge, in the Baisun mountains, was found in TASH:

Uzbekistan: Western Gissar, Hoja Gur-gur Ata mountains, western side of the Bel-auti pass, upper part of slopes, 30 VI 1961, Pryahin, sn (TASH).

These specimens are represented by plants which are 5-10 $\mathrm{cm}$ tall with pods having short white bristles. Kovalevskaja (1981) regarded such plants as a rare variant, because the typical specimens have pods without bristles. Thus, the westernmost part of the distribution area of this species is limited by the Baisun mountains.

\section{Onobrychis cornuta (L.) Desv.}

In the flora of Central Asia, O. sect. Dendrobrychis DC. is represented by two species, $O$. echidna Lipsky and $O$. cornuta (L.) Desv . These form dense spiny cushions with short flowering stems. Onobrychis cornuta differs from O. echidna in its fork-branched flowering stems which become spines when lignified with age (O. ser. Dielsianae Širj.), whereas the second species has simple lignified spines which are formed from petioles $(O$. ser. Litvinovianae Šrj.). The distribution area of $O$. cornuta includes the Kopet-Dag mountains, Great Balhans, and small isolated areas in Pamir-Alay (Kovalevskaja 1981). The Alay part of this distribution area includes the following records from Uzbekistan (Fig. 2): 
Uzbekistan: Fergana Valley, Soh river basin, Zarhar-say river, in the Juniper zone, $25 \mathrm{~V}$ 1950, Korotkova, 2656; Pamir-Alay, Alay ridge, Shahimardan river basin, at the Shivali pass, 11 VII 1967, Khalkuziev, sn; Western part of Alay ridge, vicinity of Shahimardan village, 12 VI 1964, Shonazarov, 2514; Alay ridge, vicinity of Shahimardan village, behind Green lake, $2450 \mathrm{~m}$ above sea level, 28 VIII 1948, Shafeev, sn (TASH).

\section{Trigonella iskanderii Vassilcz. [Melissitus iskanderi (Vass.) Latsch.]}

According Kinzikaeva (1978) and (Shermatov 1981), the species is an endemic of Tajikistan. One specimen of T. iskanderii collected from Uzbekistan on the periphery of the Western Tian-Shan shows a significant disjunction:

Uzbekistan: Western Tian-Shan, Kurama mts., Abyas river valley, mountain farm, road to the Abyas pass, 16 VII 1935, T. Lopott, 243 (TASH).

This finding is consistent with the idea of the proximity of the flora of the Kurama ridge to the Pamir-Alay (Kamelin 1973, 1990; Tojibaev 2010), particularly to Kuhistan (Korovin 1962).

\section{References}

Abdullaeva, M.N., Kovalevskaja, S.S., Kamelin R.V. \& al. 1981: Astragalus L. - Pp. 70-281 in: Kamelin, R.V., Kovalevskaja, S.S. \& Nabiev, M.M. (Ed.), Conspectus Florae Asiae Mediae, 6. - Tashkent [in Russian].

Abdusalamova, L.N. 1978: Oxytropis DC. - Pp. 426-496 in: Ovczinnikov, P.N. (Ed.), Flora of Tajikistan, 5. - Leningrad [in Russian].

Borissova, A.G., Gontscharow, N.F., Gorschkova, S.G., Popov, M.G. \& Vassilczenko, I.T. 1946: Astragalus L. - 915 pp. in: Schischkin, B.K. (Ed.), Flora of the USSR, 12. - Moscow \& Leningrad [in Russian].

Filimonova, Z.N. 1983: Oxytropis DC. - Pp. 323-368 in: Adylov, T.A. (Ed.), Conspectus Florae Asiae Mediae, 7. - Tashkent [in Russian].

Gontscharow, N.F. 1955: Astragalus L. - Pp. 473-671 in: Vvedensky, A.I. (Ed.), Flora of Uzbekistan, 3. - Tashkent [in Russian].

- 1955: Oxytropis DC. - Pp. 686-714 in: Vvedensky, A.I. (Ed.), Flora of Uzbekistan, 3. - Tashkent [in Russian].

Kamelin, R.V. 1973: Florogenetic analysis of the native flora of the Mountain Middle Asia. Leningrad [in Russian].

- 1990: Flora of Syr Darya Karatau: Materials for floristic regionalization of Middle Asia. Leningrad [in Russian].

Khalkuziev, P.Kh. 1971: The flora and vegetation of Shahimardan river basin: Abstract of PhD dissertation. - Tashkent [in Russian].

Kinzikaeva, G.K. 1978: Melisittus Medik. - Pp. 313-328 in: Ovczinnikov, P.N. (Ed.), Flora of Tajikistan, 5. - Leningrad [in Russian].

Korotkova, E.E. 1955: Hedysarum L. - Pp. 722-736 in: Vvedensky, A.I. (Ed.), Flora of Uzbekistan, 3. - Tashkent [in Russian].

Korovin, E.P. 1962: Vegetation of Central Asia and Southern Kazakhstan, 2. Ed. 2. - Tashkent [in Russian].

Kovalevskaja, S.S. 1981: Hedysarum L. - Pp. 286-311 in: Kamelin, R.V., Kovalevskaja, S.S. \& Nabiev, M.M. (Ed.), Conspectus Florae Asiae Mediae, 6. - Tashkent [in Russian].

- 1981: Onobrychis Mill. - Pp. 311-321 in: Kamelin, R.V., Kovalevskaja, S.S. \& Nabiev, M.M. (Ed.), Conspectus Florae Asiae Mediae, 6. - Tashkent [in Russian]. 
Krasovskaya, L.S. \& Levichev, I.G. 1986: Flora of Chatqal Nature Reserve. - Tashkent [in Russian]. Lazkov, G.A. \& Sultanova, B.A. 2011: Checklist of vascular plants of Kyrgyzstan. -Norrlinia 24: 1-166. Shermatov, G.M. 1981: Trigonella L. - Pp. 20-26 in: Kamelin, R.V., Kovalevskaja, S.S. \& Nabiev, M.M. (Ed.), Conspectus Florae Asiae Mediae, 6. - Tashkent [in Russian].

Takhtajan, A.L. 1986: Floristic regions of the world. - Berkeley-Los Angeles-London.

Tojibaev, K.Sh. 2010: Flora of South-Western Tian Shan (within the Republic of Uzbekistan). Tashkent [in Russian].

Vinogradova, R.M. \& Kamelin, R.V. 1981: Chesneya Lindl. - Pp. 64-70 in: Kamelin, R.V., Kovalevskaja, S.S. \& Nabiev, M.M. (Ed.), Conspectus Florae Asiae Mediae, 6. - Tashkent [in Russian].

Vvedensky, A.I. 1955: Chesneya Lindl. - Pp. 470-473 in: Vvedensky, A.I. (Ed.), Flora of Uzbekistan, 3. - Tashkent [in Russian].

Addresses of the authors:

Komiljon Tojibaev, Natalya Beshko, Orzumat Turginov \& Dilafruz Mirzalieva,

Central Herbarium of Uzbekistan (TASH); Institute of Gene Pool of Plants and Animals, of the Academy Sciences of Uzbekistan, 100125, Durmon yuli str., 32, Tashkent Uzbekistan 
